\title{
Apolipoprotein A-I (Glu 198 $\rightarrow$ Lys): A Mutant of the Major Apolipoprotein of High-Density Lipoproteins Occurring in a Family with Dyslipoproteinemia
}

\author{
WOLFGANG STROBL, HANS-ULLRICH JABS, MICHAEL HAYDE, THERESIA HOLZINGER, \\ GERD ASSMANN, AND KURT WIDHALM \\ Department of Pediatrics, University of Vienna, Vienna, Austria [W.S., M.H., T.H., K.W.] and Institut für \\ Klinische Chemie und Laboratoriumsmedizin, Medizinische Einrichtungen der Westfälischen Wilhelms- \\ Universität Münster, Münster, GFR [H-U.J., G.A]
}

\begin{abstract}
To detect genetic mutants of apo A-I, the major structural protein of human HDL, we screened 530 unrelated Austrian probands (168 children, 362 adults). An apo A-I mutant characterized by an exchange of the acidic amino acid Glu in position 198 with the basic amino acid Lys was identified in the serum of the mother of a hyperlipoproteinemic girl. So far only two patients with this mutant, referred to as apo A-I (Glu 198 $\rightarrow$ Lys) have been described. We detected six new patients (two children and four adults) with apo A-I (Glu 198 $\rightarrow$ Lys) among 20 members in three generations of the affected family. An autosomal codominant inheritance of the apolipoprotein variant could be established. All affected individuals were heterozygous for the mutant. Among the six new subjects with apo A-I (Glu 198 $\rightarrow$ Lys) two children and one adult presented with high-density lipoprotein (HDL) cholesterol concentrations below the fifth percentile for age and sex and with low serum apo A-I and A-II. Although there was no consistent relationship of the mutant with low serum HDL in this family, a moderate effect of apo A-I (Glu $198 \rightarrow$ Lys) on HDL levels cannot be ruled out. Hyperlipoproteinemia of types IIa, IIb, and IV was observed in eight of the $\mathbf{2 0}$ family members studied, but did not cosegregate with the mutant apo A-I. There was no association of apo A-I (Glu 198 $\rightarrow$ Lys) with premature clinical manifestations of atherosclerosis. The mutation occurred in a part of the apo A-I molecule, which is thought to be involved in lipid binding. The mutant apo A-I, however, was almost exclusively bound to HDL, similar to normal apo A-I. Although apo A-I (Glu 198 $\rightarrow$ Lys) does not appear to be related to dyslipoproteinemia or premature atherosclerosis, this apolipoprotein variant may be of interest in studying the interaction of HDL with cell surface receptors and for genetic mapping studies. (Pediatr Res 24: 222-228, 1988)
\end{abstract}

\section{Abbreviations}

VLDL, very low-density lipoproteins $(d>1.006)$

LDL, low-density lipoproteins (d 1.006-1.063)

HDL, high-density lipoproteins (d 1.063-1.21)

$C$, cholesterol

TG, triglycerides

Received June 11, 1987; accepted April 13, 1988

Correspondence Dr. W. Strobl, Baylor College of Medicine, Department of Internal Medicine, Fannin 6565, Mailstation A-601, Houston, TX 77030. Supported in part by a grant from Anton Dreher Gedächtnisstiftung oler Univ. Wien.

\author{
VLDL-C, LDL-C, HDL-C, VLDL-, LDL-, HDL-choles- \\ terol \\ apo A-I, A-II, B, C-III, E: apolipoproteins A-I, A-II, B, C- \\ III, $\mathbf{E}$ \\ LCAT, lecithin:cholesterol acyltransferase \\ SDS, sodium dodecylsulfate \\ HPLC, high-performance liquid chromatography
}

It is well established that disorders of lipoprotein metabolism play a central role among the risk factors for premature coronary heart disease (1). In adult populations elevated serum levels of total cholesterol and LDL-C and increased levels of HDL-C are associated with an increased risk for coronary heart disease (1). Recently, it has been proposed that the apolipoproteins, the protein moieties of the lipoprotein particles, may be even better predictors of atherosclerosis than HDL- or LDL-C (2). In adult patients, coronary heart disease is positively correlated to the serum levels of apo B, the protein constituent of LDL and inversely related to apo A-I, the predominant protein of $\mathrm{HDL}$ $(3,4)$.

Serum lipoprotein levels in children are closely related to the extent of early atherosclerotic lesions (5) and to the prevalence of premature coronary artery disease in their parents (6). The levels of apo A-I and B in children appear to be even more closely associated with the prevalence of myocardial infarction in the parents than LDL-C or HDL-C (7).

Apo A-I is a polypeptide of 243 amino acids of known sequence (8). Apo A-I is secreted into the bloodstream by the liver and intestine as a proprotein, which is then rapidly converted to mature apo A-I (9). Two major isoforms of mature normal apo A-I, which arise by deamidation, can be separated in human serum (10). The protective role of apo A-I in the pathogenesis of atherosclerosis is not completely understood. It is assumed that apo A-I participates in the transport of cholesterol from peripheral tissues to the liver (11), the only organ capable of $\mathrm{C}$ disposal. In this transport process, apo A-I acts as cofactor of the enzyme LCAT, which catalyzes the formation of $C$ esters in serum (12) and may also be involved in the binding and uptake of HDL by specific cell surface receptors (13).

Structural mutants of apolipoproteins can be used to study the role of the apolipoproteins in lipoprotein metabolism and atherosclerosis. Recently, several rare variants of human apo A-I have been discovered and some of them have been characterized concerning their difference in primary structure as compared to normal apo A-I (14-23). Here, we report on an apo A-I variant 
that we discovered in the family of a hyperlipoproteinemic girl during a screening program.

\section{SUBJECTS AND METHODS}

A total of 530 unrelated Austrian probands ( 168 children, 362 adults) was screened for apo A-I variants. The probands had been referred to the lipid outpatient clinic for suspected hyperlipidemia, for follow-up of known hyperlipoproteinemia or study during cardiovascular rehabilitation. A total of 210 of these probands was hyperlipidemic with serum $\mathrm{C}<250 \mathrm{mg} / \mathrm{dl}$ and/or triglycerides $>300 \mathrm{mg} / \mathrm{dl}$ in adults or with serum C $>220 \mathrm{mg} / \mathrm{dl}$ and/or TG $>250 \mathrm{mg}$ in children, 320 were normolipidemic. A total of 159 of the subjects was survivors of myocardial infarction or suffered from coronary artery disease.

Among this study population one family with an apo A-I mutant was detected. A medical history was obtained and a short physical examination was performed on all members of this family. A routine clinical chemistry program including tests for hepatic and renal function, serum electrolytes, blood sugar, and blood count was carried out. The family members affected with the apo A-I variant were examined for signs of atherosclerosis by ECG and Doppler sonography of the great arteries of the lower limbs and of the carotid arteries.

Blood samples were collected after an overnight fast. Blood was allowed to clot at room temperature and serum was separated by low speed centrifugation. Sera were stored at $4^{\circ} \mathrm{C}$ for up to 1 wk before lipid and lipoprotein determination or at $-20^{\circ} \mathrm{C}$ until analyzed for apo A-I mutants.

Serum $\mathrm{C}$ and TG were determined by enzymatic methods ( 24 25). In accordance with Lipid Research Clinic methods (26) serum lipoproteins were separated by a combination of ultracentrifugation and polyanionprecipitation for the determination of lipoprotein C. Serum apo A-I, apo A-II, and apo B were determined by electroimmunoassay using commercially available monospecific antibodies (Immuno Diagnostika, Vienna, Austria) as described previously (27).

Screening for variants of apo A-I was performed by isolectric focusing as described by Menzel et al. (14). Native serum, after incubation with decylsulfate and mercaptoethanol, was focused on vertical $7.5 \%$ polyacrylamide slab gels containing $6 \mathrm{M}$ urea in a $\mathrm{pH}$ gradient from 4 to 6 . The immunoreactivity of the protein bands separated by isoelectric focusing was established by immunoelectrophoresis against monospecific anti apo A-I and anti apo A-II in the second dimension and by two-dimensional gel electrophoresis (14) of immunoprecipitates prepared from whole serum with monospecific anti apo A-I (28). Mol. wt. was determined by second dimension SDS gel electrophoresis using the discontinuous gel system of Neville (29).

VLDL ( $<$ 1.006), LDL (d 1.006-1.063), and HDL (d 1.0631.21) were isolated by sequential preparative ultracentrifugation (30). The fractions were dialyzed against $0.15 \mathrm{M} \mathrm{NaCl}, \mathrm{pH} 7.4$ and delipidated twice with ethanol/diethylether $(3+1)$ and once with diethylether alone. Apolipoproteins were dissolved in 0.02 $\mathrm{M}$ Tris/ $\mathrm{HCl}, \mathrm{pH} 8.2,1.5 \%$ decylsulfate, and $8 \mathrm{M}$ urea in the presence of mercaptoethanol. The occurrence of the mutant apo A-I in the isolated lipoprotein fractions was studied by isoelectric focusing in a gradient from $\mathrm{pH} \mathrm{4-6}$ as described above. Apo E phenotypes were determined by isoelectric focusing of delipidated VLDL in $7.5 \%$ polyacrylamide slab gels containing $6 \mathrm{M}$ urea in a $\mathrm{pH}$ gradient from 4-7.5 (31).

For the determination of the amino acid substitution in the mutant apo A-I normal and mutant apo A-I was isolated from HDL by preparative isoelectric focusing on Immobiline gel (32). The fractions were eluted electrophoretically and dialyzed extensively against $0.05 \mathrm{M}$ sodium bicarbonate, $\mathrm{pH} 7.4$ and then subjected to digestion with trypsin (Sigma, Munich, West Germany) in a ratio of $1: 40$ at $37^{\circ} \mathrm{C}$ overnight. The tryptic peptides were separated by reverse phase HPLC using a C18 column with a gradient $(1-40 \%$ in $60 \mathrm{~min})$ of $0.1 \%$ trifluoroacetic acid and acetonitrile and analyzed by time-of-flight secondary ion mass spectrometry (32). Microsequence analysis of HPLC-separated peptides was performed by the 4-N,N-dimethylaminoazobenzene-4'isothiocyanate/phenylisothiocyanate double coupling method as described earlier (32).

The Mann Whitney U test was used for statistical comparison of the lipoprotein and apolipoprotein values in the probands with the apo A-I mutant with those in their unaffected family members because the data did not follow a normal distribution.

\section{RESULTS}

Characterization of mutant apo A-I. During the screening project, a 15-yr-old girl with type IIa hyperlipoproteinemia (III9 in Fig. 1) was referred to the lipid outpatient clinic. When her first degree relatives were studied, a variant of apo A-I was identified in the serum of the girl's mother, a 32-yr-old woman with type IIa hyperlipoproteinemia (II 7 in Fig. 1). All of the other 529 patients screened for apo A-1 mutants had a normal apo A-I isoprotein pattern. All available relatives of the proband with the mutant were investigated. Twenty family members from three generations of the kindred with the apo A-I mutant participated in this family study (Fig. 1). Five blood relatives of the proband (II-7) were found to be affected with the mutant apo AI. Among them there was an identical twin (II-8) of the proband (II-7).

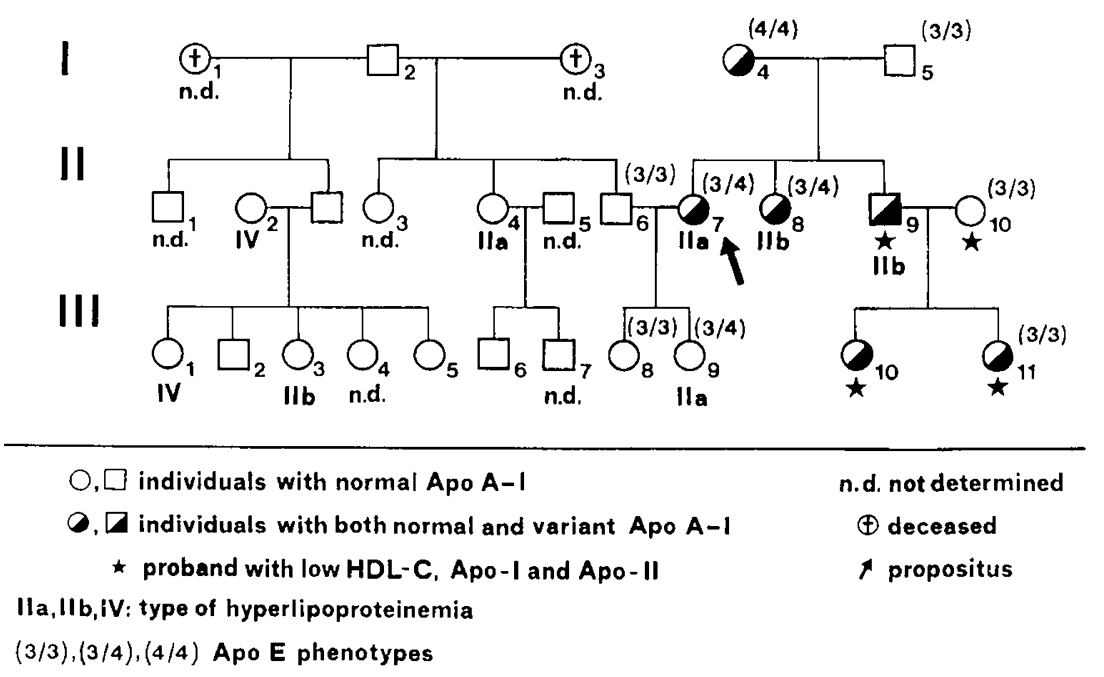

Fig. 1. Pedigree of a kindred with apo A-I (Glu 198 $\rightarrow$ Lys). 
On isoelectric focusing gels of native serum from the individuals with the apo A-I mutant, two additional protein bands appeared that differed from the two major normal apo A-I isoproteins (apo A-I-1 and apo A-I-2) (14) by a charge difference of +2 units (Fig. 2). The immunoreactivity of the abnormal bands with monospecific apo A-I antiserum could be established (Fig. 2). Immunoelectrophoresis of the serum of the proband (II7) showed that the normal and the variant apo A-I were present in approximately equal amounts. The mol. wt. of the mutant protein was identical to that of normal apo A-I (approximately $28.6 \mathrm{kDa}$ ). This was determined by two dimensional SDS gel electrophoresis of native serum (not shown) or immunoprecipitates prepared from whole serum using monospecific apo A-I antibody (Fig. 3). The chromatograms obtained by reverse phase HPLC of the tryptic peptides of the mutant apo A-I were characterized by the disappearance of peak T32 (mol. wt. $1215 \mathrm{Da}$ ) containing amino acids 196-206 of normal apo A-I (Table 1) and the presence of an abnormal peak designated as T32x with a molecular mass of $913 \mathrm{Da}$, as determined by time-of-flight secondary ion emission mass spectrometry. These findings suggested the introduction of a new trypsin cleavage site at position 198 by an amino acid exchange of Glu by Lys. Manual microsequence analysis of the abnormal peptide confirmed this amino acid exchange (Table 1). The mutant is therefore referred to as apo A-I (Glu 198 $\rightarrow$ Lys).

Figure 4 shows a helical wheel presentation (33) of the segment of normal and mutant apo A-I containing amino acids 190-207. In this part of the sequence the amino acids are arranged in an amphipatic helix, i.e. a helical structure with one side that is apolar and carries hydrophobic amino acids, whereas the other face is polar (34). In the model of the sequence neighboring the mutation the amphipathic structure appears intact. In normal apo A-I, three Glu residues are located on the hydrophilic face of this helix. This acidic region of the molecule is interrupted by the basic Lys at position 198 in the mutant.

Lipoprotein distribution of apo A-I (Glu $198 \rightarrow L y s)$. VLDL, LDL, HDL, and the $\mathrm{d}>1.21$ fraction of serum from three probands with the mutant and from an unaffected relative were isolated by preparative ultracentrifugation and analyzed by isoelectric focusing in a $\mathrm{pH}$ gradient from 4-6 as described above. The mutant apo A-I was almost exclusively bound to HDL (Fig. 5). The isoprotein pattern of apo C-III, which is closely linked to apo A-I in the genome (35), was normal in the patients with apo A-I (Glu 198 $\rightarrow$ Lys).

Genetics of apo A-I (Glu 198 $\rightarrow$ Lys). Vertical transmission of the trait over three generations of the affected kindred could be demonstrated (Fig. 1). Inspection of the pedigree suggests that apo A-I (Glu 198 $\rightarrow$ Lys) is inherited as autosomal codominant trait. All affected individuals were heterozygotes having normal apo A-I in addition to the mutant.

Apo A-I (Glu 198 $\rightarrow$ Lys) and dyslipoproteinemia. In the kindred with apo A-I (Glu 198 $\rightarrow$ Lys) described here, three of the six family members with the mutant (two children and one adult) presented with serum HDL-C levels below the fifth percentile for age and sex $(36,37)$ (II-9, III-10, III-11 in Fig. 1 and Table 2). In contrast, only one of the 15 unaffected siblings had low HDL-C (II-10 in Fig. 1 and Table 2). The apo A-I and apo A-II concentrations in the three patients with apo A-I (Glu 198 $\rightarrow$ Lys) and decreased HDL-C appear to be low (Table 2) when compared to those of the unaffected family members. The apo A-I levels of both
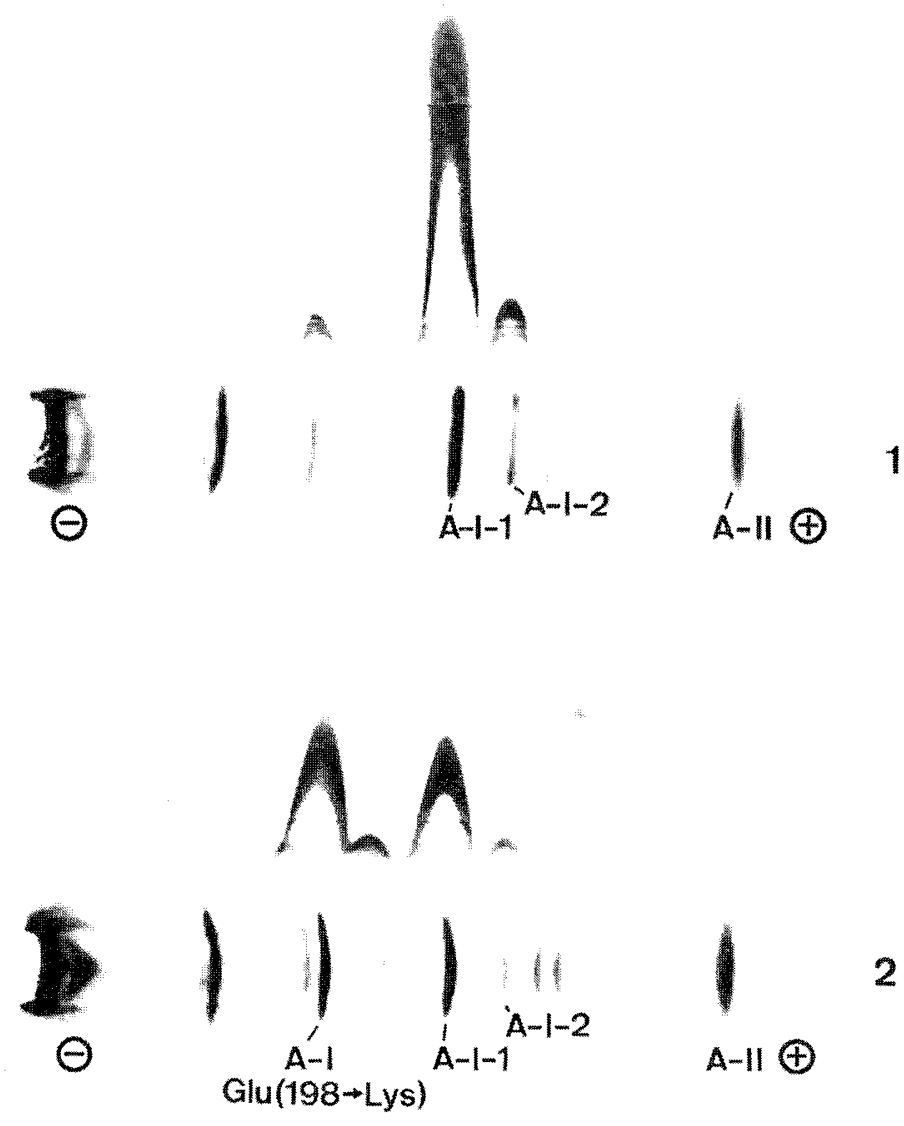

Fig. 2. Isoelectric focusing ( $\mathrm{pH} 4-6$ ) (horizontal) of native serum followed by immunoelectrophoresis (vertical) using monospecific anti apo A-I. Upper panel, control; lower panel, patient with apo A-I (Glu 198 $\rightarrow$ Lys). 
children affected with the mutant (III-10, III-11 in Fig. 1 and Table 2) were below the fifth percentile of reference values in a large pediatric population determined by a method comparable to the one used here (38). The mean values for serum HDL-C apo A-I and apo A-II for all six probands with the mutant, however, did not differ significantly from those for their relatives without it (Table 2).

No consistent association of apo A-I (Glu 198 $\rightarrow$ Lys) with hyperlipoproteinemia could be established (Fig. 1). The proband identified during the screening (II-7) had type IIa hyperlipoproteinemia. Her twin sister (II-8) and her brother (II-9), both also heterozygous for the mutant, presented with type IIb hyperlipo-

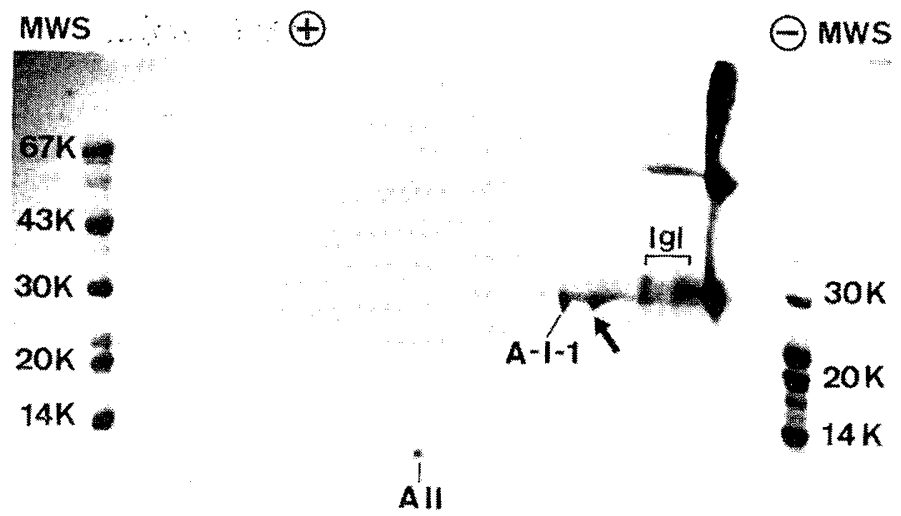

$\oplus$

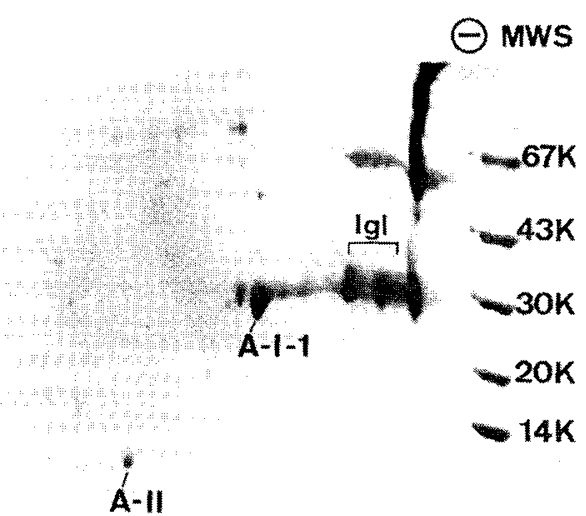

Fig. 3. Two-dimensional SDS gel electrophoresis of immunoprecipitates prepared from normal serum (lower panel) and from serum of a patient heterozygous for apo A-I (Glu 198 $\rightarrow$ Lys) (upper panel) using monospecific anti apo A-I. $M W S$, molecular weight standard; $K$, kilodalton; $I g l$, immunoglobulin light chains. Arrow denotes apo A-I (Glu $198 \rightarrow$ Lys). proteinemia. In contrast, the three other blood relatives with apo A-I (Glu 198 $\rightarrow$ Lys), one adult (I-4) and two children (III-10 and III-11), were not hyperlipoproteinemic. Moreover, hyperlipoproteinemia was diagnosed in five of the 14 members of the kindred, who were unaffected by the mutant apo A-I (II-2, II-4, III-1, III3, III-9). The mean serum levels of total C, TG, LDL-C, VLDL$C$, and apo B did not differ significantly between family members with apo A-I (Glu 198 $\rightarrow$ Lys) and their relatives without the mutant (Table 1).

Apo E phenotypes and dyslipoproteinemia. Apo E phenotypes could be determined in nine individuals of the kindred with apo A-I (Glu 198 $\rightarrow$ Lys) (Fig. 1). Hyperlipoproteinemia occurred in
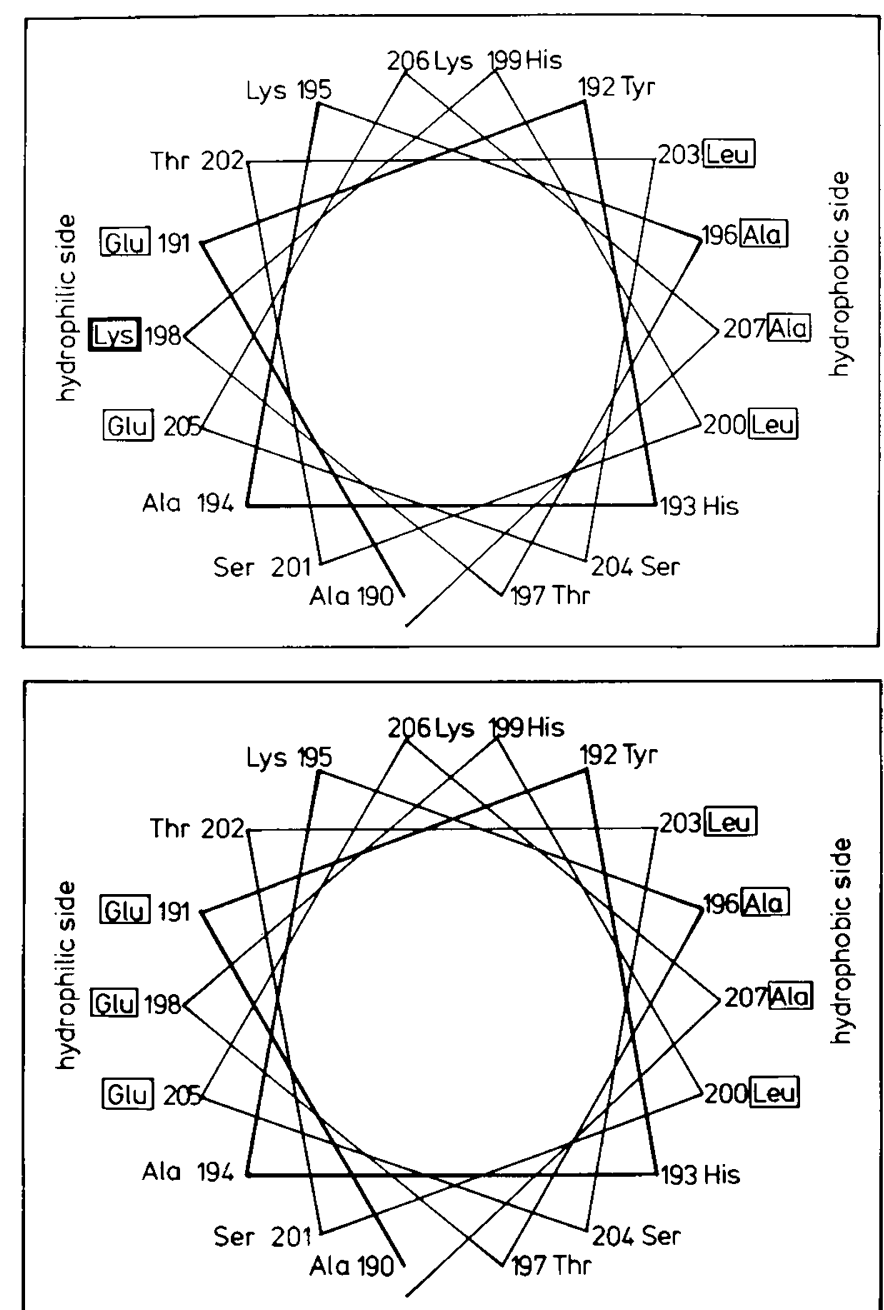

Fig. 4. Helical wheel representation of a segment of normal apo A-I (lower panel) and apo A-I (Glu 198 $\rightarrow$ Lys) (upper panel) containing amino acids 190-207. The helix extends clockwise through the plane of the page (from Ala 190 to Ala 207).

Table 1. Amino acid substitution in variant Apo A-I*

(A) Tryptic peptide $\mathrm{T} 32$ of normal apo A-I

$$
\begin{gathered}
\text { Ala }- \text { Thr }-G l u^{198}-\text { His }- \text { Leu }- \text { Ser }- \text { Thr }- \text { Leu }- \text { Ser }- \text { Glu }- \text { Lys } \\
\text { mol. wt. }=1215 \mathrm{Da}
\end{gathered}
$$

(B) Tryptic peptide T32x of variant apo A-I:

$$
\begin{gathered}
\text { Ala }- \text { Thr }- \text { Lys }^{198} \mid \dagger \text { His }- \text { Leu }- \text { Ser }- \text { Thr }- \text { Leu }- \text { Ser }- \text { Glu }- \text { Lys } \\
\text { mol. wt. }=913 \mathrm{Da}
\end{gathered}
$$

\footnotetext{
* The mol. wt. (as determined by time-of-flight secondary ion mass spectroscopy) and amino acid sequences (determined by manual microsequencing) of tryptic peptide T32 of normal apo A-I (A) and of the abnormal tryptic peptide T32x of apo A-I (Glu 198 $\rightarrow$ Lys) (B) are given.

† Denotes new tryptic cleavage site introduced by the exchange of Glu 198 with Lys in the mutant.
} 
HDL (d: 1,063-1,21)

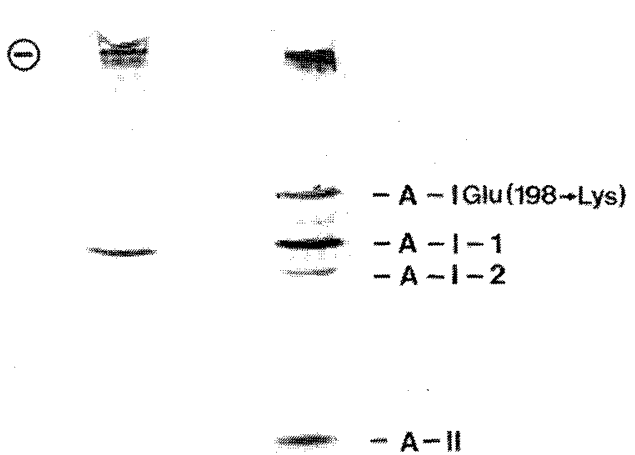

$\oplus$

normal variant
$\operatorname{VLDL}(d<1,006)$

$\Theta$
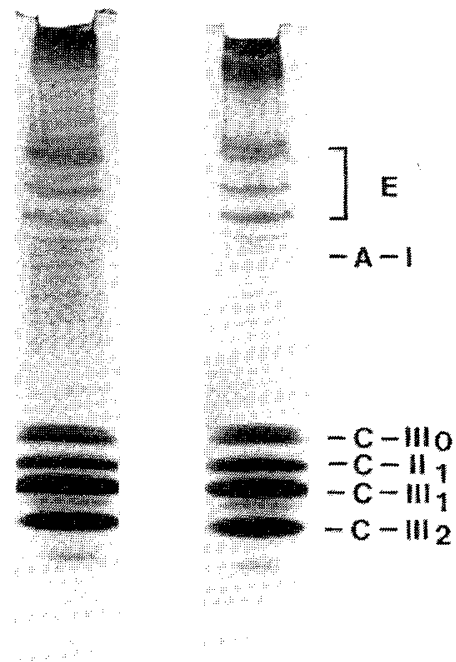

$\oplus$

normal

Fig. 5. Isoelectric focusing ( $\mathrm{pH} 4-6$ ) of delipidated HDL and VLDL from a proband with normal apo A-I (left) and from a patient heterozygous for apo A-I (Glu 198 $\rightarrow$ Lys) (right).

Table 2. Serum lipids, lipoprotein-C, apo A-I, A-II, and B in a kindred with apo A-I (Glu 198 $\rightarrow L y s)(m g / d l, m e a n s \pm S D)$

\begin{tabular}{|c|c|c|c|c|c|c|c|c|c|c|}
\hline \multicolumn{11}{|c|}{ 1) Siblings with apo A-I(Glu $198 \rightarrow$ Lys), $n=6$} \\
\hline No. & Age & Sex & $\mathrm{C}$ & TG & LDL-C & HDL-C & VLDL-C & A-I & A-II & B \\
\hline I-4 & 67 & $\mathrm{~F}$ & 136 & 112 & 78 & 44 & 14 & 129 & 28 & 76 \\
\hline II-7 & 33 & $\mathrm{~F}$ & 288 & 114 & 226 & 37 & 25 & 107 & 37 & 188 \\
\hline II-8 & 33 & $\mathrm{~F}$ & 373 & 131 & 255 & 74 & 44 & 168 & 49 & 307 \\
\hline II-9 & 35 & M & 271 & 225 & 212 & 20 & 48 & 85 & 28 & 173 \\
\hline III- 10 & 11 & $\mathrm{~F}$ & 119 & 59 & 75 & 31 & 12 & 74 & 24 & 80 \\
\hline III-11 & 14 & $\mathrm{~F}$ & 173 & 59 & 137 & 32 & 04 & 94 & 28 & 98 \\
\hline $\bar{x} \pm S D$ & $33 \pm 20 y r$ & & $227 \pm 100$ & $117 \pm 61$ & $164 \pm 78$ & $40 \pm 19$ & $25 \pm 18$ & $110 \pm 34$ & $32 \pm 9$ & $154 \pm 89$ \\
\hline
\end{tabular}

2) Siblings without apo A-I(Glu $198 \rightarrow$ Lys), $n=14(6 \mathrm{M}, 8 \mathrm{~F})$

\begin{tabular}{ccccccccccc} 
& Age & C & TG & LDL-C & HDL-C & VLDL-C & A-I & A-II & B \\
\hline$\overline{\mathrm{x}} \pm \mathrm{SD}$ & $30 \pm 21$ & $240 \pm 60$ & $186 \pm 165$ & $163 \pm 52$ & $46 \pm 13$ & $31 \pm 29$ & $116 \pm 49$ & $38 \pm 15$ & $127 \pm 54$ \\
\hline$p$ & NS & NS & NS & NS & NS & NS & NS & NS & NS \\
\hline
\end{tabular}

NS, $p>0.05$, as compared to probands with apo A-I (Glu 198 $\rightarrow$ Lys), Mann-Whitney U test.

three of four probands carrying the E4 allele (II-7, II-8, III-9), but in none of five patients without an apo E4 allele.

Clinical features of the patients with apo A-I (Glu $198 \rightarrow$ Lys). Clinical examination and routine laboratory tests revealed liver cirrhosis, obesity, and lichen urticatus in patient I-4. Cholelithiasis was diagnosed in proband II-7. Patient II-9 was obese and reported to smoke 30 cigarettes daily. Both children affected with the mutant were apparently healthy.

Neither medical history, clinical examination, ECG, or Doppler sonography of the carotid arteries and the arteries of the lower extremities revealed any symptoms or signs of atherosclerosis in the family members heterozygous for apo A-I (Glu $198 \rightarrow$ Lys).

\section{DISCUSSION}

The results of our study indicate that the apo A-I variant detected in the course of our screening program differs from normal apo A-I by a substitution of the basic amino acid Lys for the acidic amino acid Glu at position 198. This amino acid exchange accounts for the charge difference of +2 units as compared to normal apo A-I on isoelectric focusing gels. An apo A-I mutant with a similar electrophoretic mobility has recently been reported (16). This mutant is characterized by a substitution of Lys for Glu at position 136, and is thereby clearly distinct from the one described here (23).

So far only two patients with apo A-I (Glu $198 \rightarrow$ Lys) have been described (17). Apo A-I (Glu 198 $\rightarrow$ Lys) has been identified for the first time in a hyperlipoproteinemic man during a population study carried out in Münster (GFR) and was referred to as apo A-I Münster 4 (17). One additional subject with this apo A-I variant was detected in Marburg (GFR). No family study of apo A-I (Glu 198 $\rightarrow$ Lys) has been reported.

In our study we describe a kindred with six new individuals affected with apo A-I (Glu 198 $\rightarrow$ Lys). We could establish the genetic transmission of this mutant, which appears to be inherited in an autosomal codominant way. A familial nature of the mutation has also been reported for several of the other apo A-I mutants and an autosomal codominant inheritance has been proposed for some of them $(14,16,20,21)$. 
The kindred with apo A-I (Glu 198 $\rightarrow$ Lys) described here also provided the first opportunity to investigate if there exists a relationship of this apo A-I mutant with dyslipoproteinemia or atherosclerosis. This question appeared to be of particular interest, as both the patient with apo A-I (Glu 198 $\rightarrow$ Lys) identified in our screening study and the proband first described in Münster (17) were hyperlipoproteinemic. Although a high percentage of both the adults (five of 10) and the children (three of nine) in the affected kindred had hyperlipoproteinemia of types IIa, IIb, or IV, no consistent relationship between apo A-I (Glu 198 $\rightarrow$ Lys) and hyperlipoproteinemia could be demonstrated (Fig. 1). The occurrence of hyperlipoproteinemia of types IIa, IIb, and IV in the same family suggests the diagnosis of familial combined hyperlipoproteinemia (39). Although the apo E phenotype could be determined only in part of the family, hyperlipoproteinemia appeared to be more common in patients with the E4 allele than in others. This finding agrees with reports on an increased prevalence of the apo E4 allele in patients with hypercholesterolemia (40).

It seems remarkable, however, that both children affected with apo A-I (Glu 198 $\rightarrow$ Lys) (III-10, III-11) and their father (II-9), also heterozygous for the mutant, had decreased serum HDL-C, apo A-I, and apo A-II levels. Moreover, the serum concentrations of these HDL constituents were considered to be at the lower border of the normal range in the proband with the mutant, who was initially identified in our screening program (II-7). However, the HDL-C, apo A-I, and apo A-II concentrations were normal in two of the remaining six individuals with apo A-I (Glu 198 $\rightarrow$ Lys). The interpretation of these results is complicated by the occurrence of several factors in the kindred that are known to affect HDL-C and apo A-I levels, such as cigarette smoking, obesity, and liver disease $(41,21)$. In addition, all family members with the mutant were heterozygotes, in whom the normal apo A-I allele could compensate for a possible effect of the mutant allele on serum HDL. Based on the family data presented here, it is therefore neither possible to show a consistent relation of apo AI (Glu 198 $\rightarrow$ Lys) with low HDL-C, apo A-I or apo A-II nor to exclude a moderate effect of the variant on HDL levels. The first patient with apo A-I (Glu 198 $\rightarrow$ Lys) reported from Münster (GFR) (17) presented with a normal HDL concentration.

As with observations in most other apo A-I variants (15-17, 19-21), there was no evidence for accelerated atherosclerosis in our patients with apo A-I (Glu 198 $\rightarrow$ Lys). In contrast, a congenital deficiency of apo A-I and C-III is associated with severe premature arterial disease (43).

The amino acid substitution in apo A-I (Glu 198 $\rightarrow$ Lys) does not appear to disrupt the structure of the apo A-I molecule. This may explain the lack of a major effect of the mutation on serum lipoprotein levels. The amino acid exchange is located in a region of the apo A-I molecule, which is considered to be important for its lipid binding properties (34) due to its amphipathic helical structure. The apolar face of the amphipatic helix is thought to interact with the fatty acyl residues of phospholipids, whereas the polar face may interact with the polar head groups of phospholipid. In apo A-I (Glu 198 $\rightarrow$ Lys) the mutation occurred on the polar side, without interfering with the amphipatic character of the helix (Fig. 4). The lipid binding properties of the entire apo A-I (Glu 198 $\rightarrow$ Lys) molecule seem to be intact, as we observed a normal distribution of the mutant apo A-I among the lipoprotein density classes. The alteration of the charge on the hydrophilic face of the helix, which is predicted to occur in apo A-I (Glu 198 $\rightarrow$ Lys), could affect the interaction of the mutant protein with cellular HDL receptors. Inasmuch as several of the family members with apo A-I (Glu 198 $\rightarrow$ Lys) had low serum HDL-C, apo A-I, and apo A-II, receptor binding studies of the isolated mutant apo A-I should be carried out.

In contrast to apo A-I (Glu 198 $\rightarrow$ Lys), a mutation resulting in an exchange of Cys for Arg at position 173 (apo A-I Milano) (15) has been shown to disrupt one of the amphipatic helices of apo A-I and is associated with severe dyslipoproteinemia. Re- placement of Pro by Arg at position 143 (apo A-I Giessen) (21), appears to result in the elimination of a $\beta$-turn between two of the amphipathic helices of apo A-I. A deletion of Lys 107 (apo A-I Münster 2 A or Marburg) (19) is thought to change the orientation of one of the amphipathic helices by about $90^{\circ}$. Both of these apo A-I variants are defective in activating the enzyme LCAT. The LCAT activation by apo A-I (Glu 198 $\rightarrow$ Lys) described here was found to be normal in the patient first detected in Münster.

At the level of the apo A-I gene the mutation in apo A-I (Glu $198 \rightarrow$ Lys) can be explained by an alteration of the triplet GAG coding for Glu 198 (44) to AAG coding for Lys by a single base exchange in the nucleotide sequence. As all three individuals with apo A-I (Glu 198 $\rightarrow$ Lys) were detected in the neighboring countries of Germany and Austria a common origin of the mutant allele appears possible. To test this hypothesis, studies on the restriction fragment length polymorphisms of the apo AI gene in the affected subjects are currently underway.

In conclusion the data from this first family study of apo A-I (Glu 198 $\rightarrow$ Lys) suggest that this apo A-I mutant is inherited in an autosomal codominant way and does not appear to be related to either hyperlipoproteinemia or premature atherosclerosis. The mutant probably does not significantly influence HDL levels. Nevertheless apo A-I (Glu 198 $\rightarrow$ Lys) may be of interest for studying the interaction of HDL with specific cell surface receptors and for genetic mapping studies. We suggest that children and adults presenting with decreased serum HDL-C, apo A-I, or A-II should be screened for apo A-I mutants. Regardless of whether or not mutant forms of apo A-I bear a causal relationship to dyslipoproteinemia, they may provide new insight into the role of this apolipoprotein in lipoprotein metabolism.

Acknowledgments. The authors thank Dr. J. Kaliman, Department of Cardiology, University of Vienna for cardiological examinations and Ms. Nancy L. Gorder for her assistance in the preparation of the English manuscript. The technical assistance of Mrs. Barbara Kerbl and Mrs. Martha Pinezich are gratefully acknowledged.

\section{REFERENCES}

1. Kannel WB, Castelli WP Gordon T, McNamara PM 1971 Serum cholesterol, lipoproteins and the risk of coronary heart disease-the Framingham Study. Ann Intern Med 74:1-12

2. Avogaro P, Bittolo Bon GB, Cazzolato G, Quinci G, Belussi F 1979 Are apolipoproteins better discriminators than lipids for atherosclerosis? Lancet 1:901-903

3. Brunzell JD, Sniderman AD, Albers JJ, Kwiterovich PO Jr 1984 Apoproteins $\mathrm{B}$ and A-I in coronary artery disease in humans. Arteriosclerosis 4:79-83

4. Maciejko JJ, Holmes DR, Kottke BA, Zinsmeister AR, Dinh DM, Mao SJT 1983 Apolipoprotein A-I as a marker of angiographically defined coronary artery disease. N Engl J Med 309:385-389

5. Newman WP III, Freedman DS, Voors AW, Gard PD, Srinivasan SR, Cresanta JL, Williamson GD, Webber LS, Berenson GS 1986 Relation of serum lipoprotein levels and systolic blood pressure to early atherosclerosis: the Bogalusa Heart Study. N Engl J Med 314:138-144

6. Pometta D, Micheli H, Raymond L, Oberhaensli I, Suenram A 1980 Decreased HDL cholesterol in prepubertal and pubertal children of CHD patients. Atherosclerosis 36:101-109

7. Freedman D, Srinivasan S, Shear CL, Franklin FA, Webber L, Berenson G 1986 The relationship of apolipoproteins A-I and B in children to parental myocardial infarction. N Engl J Med 315:721-726

8. Brewer HB Jr, Fairwell T, La Rue RR, Houser A, Bronzert TJ 1978 The amino acid sequence of human apolipoprotein A-I, an apolipoprotein isolated from high density lipoproteins. Biochem Biophys Res Commun 80:623-630

9. Bojanovski D, Gregg RE, Ghiselli G, Schaefer EJ, Light JA, Brewer HB Jr 1985 Human apolipoprotein A-I isoprotein metabolism: proapo A-I conversion to mature apo A-I. J Lipid Res 26:185-193

10. Ghiselli G, Rhode MF, Tanenbaum S, Krishnan S, Gotto AM Jr 1985 Origin of apolipoprotein A-I polymorphism in plasma. J Biol Chem 260:1566215668

11. Eisenberg S 1984 High density lipoprotein metabolism. J Lipid Res 25:10171058

12. Fielding CJ, Shore VG, Fielding PE 1972 A protein cofactor of lecithin:cholesterol acyltransferase. Biochem Biophys Res Commun 46:14931498 
13. Schmitz G, Robenek H, Lohmann U, Assmann G 1985 Interaction of high density lipoproteins with cholesteryl ester-laden macrophages: biochemical and morphological characterization of cell surface receptor binding, endocytosis and resecretion of high density lipoproteins by macrophages. EMBO J 4:613-622

14. Menzel HJ, Kladetzky RG, Assmann G 1982 One-step screening method for the polymorphism of apolipoproteins A-I, A-II and A-IV. J Lipid Res 23:915-922

15. Weisgraber KH, Rall SC, Bersot TP, Mahley RW, Franceschini G, Sirtori, CR 1983 Apolipoprotein A-I Milano. Detection of normal A-I in affected subjects and evidence for a cysteine for arginine substitution in the variant A-I. J Biol Chem 258:2508-2513

16. Schamaun O, Olaisen B, Gedde-Dahl T Jr, Teisberg P 1983 Genetic studies of an apo A-I lipoprotein variant. Hum Genet 64:380-383

17. Assmann G, Menzel HJ, Kladetzky RG, Büttner G 1984 Frequency of apolipoprotein A-I mutants in the German population. J Clin Chem Clin Biochem 22:585-589

18. Utermann G, Feussner G, Franceschini G, Haas J, Steinmetz A 1982 Genetic variants of group A apolipoproteins. Rapid method for screening and characterization without ultracentrifugation. J Biol Chem 257:501-507

19. Rall SC, Weisgraber KH, Mahley RW, Ogawa Y, Fielding CJ, Utermann G, Haas J, Steinmetz A, Menzel HJ, Assmann G 1984 Abnormal lecithin:cholesterol acyltransferase activation by a human apolipoprotein A-I variant in which a single Lysin residue is deleted. J Biol Chem 259:1006310070

20. Menzel HJ, Assmann G, Rall SC Jr, Weisgraber KH, Mahley RW 1984 Human apolipoprotein A-I polymorphism. Identification of amino acid substitutions in three electrophoretic variants of the Münster-3 type. J Biol Chem 259:3070-3076

21. Utermann G, Haas J, Steinmetz A, Paetzold R, Rall SC Jr, Weisgraber $\mathrm{KH}$ Mahley RW 1984 Apolipoprotein A-I Giessen (Pro 143-Arg). A mutant that is defective in activating lecithin:cholesterol acyltransferase. Eur $\mathbf{J}$ Biochem 144:325-331

22. Mahley RW, Innerarity TL, Rall SC, Weisgraber KH 1984 Plasma lipoproteins: apolipoprotein structure and function. J Lipid Res 25:1277-1294

23. Rall SC, Weisgraber KH, Mahley RW, Ehnholm C, Schamaun O, Olaisen B, Blomhoff JP, Teisberg P 1986 Identification of homozygosity for a human apolipoprotein A-I variant. J Lipid Res 27:436-441

24. Richmond W 1973 Preparation and properties of a cholesterol oxidase from Nocardia sp. and its application to the enzymatic assay of total cholesterol in serum. Clin Chem 19:1350-1356

25. Buculo G, David H 1975 Quantitative determination of serum triglycerides by the use of enzymes. Clin Chim Acta 59:271-275

26. Lipid Research Clinics Program 1974 Manual of Laboratory Operations, Vol 1. Lipid and Lipoprotein Analysis. NHLI, NIH, Washington, D.C., DHEW Publ. no. 75-628

27. Strobl W, Widhalm K, Kostner G, Pollak A 1983 Serum apolipoproteins and $\mathrm{Lp}$ (a) during the first week of life. Acta Paediatr Scand 72:505-509

28. Schmitz G, Assmann G, Rall SC, Mahley RW 1983 Tangier disease: defective recombination of a specific Tangier apolipoproein A-I isoform (pro-apo A-
I) with high density lipoproteins. Proc Natl Acad Sci USA 80:6081-6085

29. Neville DM 1971 Molecular weight determination of protein-dodecylsulfate complexes by gel electrophoresis in a discontinuous buffer system. J Biol Chem 246:6328-6334

30. Havel RJ, Eder HA, Bragdon JH 1955 The distribution and chemical composition of lipoproteins in human serum. J Clin Invest 34:1345-1353

31. Menzel HJ, Kladetzky RG, Assmann G 1983 Apolipoprotein E-polymorphism and coronary artery disease. Arteriosclerosis 3:310-315

32. Jabs HU, Assmann $G$, GreifendorfD, Benninghoven A 1986 High performance liquid chromatography and time-of-flight secondary ion mass spectrometry: a new dimension in structural analysis of apolipoproteins. J Lipid Res 27:613-621

33. Schiffer M, Edmundson AB 1967 Use of helical wheels to represent the structures of proteins and to identify segments with helical potential. Biophys J 7:121-135

34. Baker HN, Gotto AM, Jackson RL 1975 The primary structure of human plasma high density apolipoprotein glutamine I (apo A-I). J Biol Chem 250:2725-2737

35. Bruns GAP, Karathanasis SK, Breslow JL 1984 Human apolipoprotein A-IC-III gene complex is located on chromosome 11. Arteriosclerosis 4:97-102

36. Tamir I, Heiss G, Glueck CJ, Christensen B, Kwiterovich PO, Rifkind BM 1981 Lipid and lipoprotein distributions in white children ages 6-19 yrs. The Lipid Research Clinics Program Prevalence Study. J Chronic Dis 34:2739

37. Heiss G, Tamir I, Davis CE, Tyroler HA, Rifkind BA, Schonfeld G, Jacobs D, Frantz ID 1980 Lipoprotein cholesterol distributions in selected North American populations: the Lipid Research Clinics Program Prevalence Study. Circulation 61:302-315

38. Srinivasan SR, Freedman DS, Sharma C, Webber L, Berenson G 1986 Serum apolipoproteins A-I and B in 2,854 children from a biracial community: Bogalusa Heart Study. Pediatrics 78:189-200

39. Goldstein JL, Schrott HG, Hazzard WR, Bierman EL, Motulsky AG 1973 Hyperlipidemia in coronary heart disease. II. Genetic analysis of lipid levels in 176 families and delineation of a new inherited disorder, combined hyperlipidemia. J Clin Invest 52:1544-1568

40. Assmann G, Schmitz G, Menzel HJ, Schulte H 1984 Apolipoprotein E polymorphism and hyperlipidemia. Clin Chem 30:641-643

41. Avogaro P, Cazzolato G, Bittolo Bon G, Quinci GB, Chinello M $1978 \mathrm{HDI}$ cholesterol, apolipoproteins A-I and B, age and index body weight. Atherosclerosis 31:85-91

42. Assmann G, Schulte H, Schriewer H 1984 The effects of cigarette smoking on serum levels of HDL cholesterol and HDL apolipoprotein A-I. J Clin Chem Clin Biochem 22:397-402

43. Norum RA, Lakier JB, Goldstein S, Angel A, Goldberg RB, Block WD, Noffze DK, Dolphin PJ, Edelglass J, Borograd DD, Alaupovic P 1982 Familial deficiency of apolipoprotein A-I and C-III and precocious coronary-artery disease. N Engl J Med 306:1513-1519

44. Cheung P, Chan L 1983 Nucleotide sequence of cloned cDNA of human apolipoprotein A-I. Nucleic Acids Res 11:3703-3715 